\title{
Impact of work life flexibility on work performance of the employees of IT Companies.
}

\author{
Dr. Lalit Prasad ${ }^{1}$ and Dr Priyanka Mishra ${ }^{2}$ \\ ${ }^{1}$ AssociateProfessor, Dr. D.Y.Patil Institute of Management Studies, Pune, India, onlylalitprasad@gmail.com \\ ${ }^{2}$ Assistant Professor, Dr. D.Y.Patil Institute of Management Studies, Pune, India, drpriyankamishra3683@gmail.com
}

\begin{abstract}
In this digital era and with the advent of technology, work life flexibility is in demand and is being practice din many organizations to support the company and employees. In lieu of the same, this paper investigates the relationship between work life flexibility and work performance. There is very limited empirical research that substantiates the relationship betweenwork life flexibility and work performance. The Sample of the study was comprised of 179 (75 male and 104 female) of employees of IT Companies. The data were collected from work life flexibility questionnaire including Job Satisfaction, Workplace Stress, Financial Reimbursement, WorkLife Balance and Job Environment. The work performance consists the components: Task Performance, Contextual Performance, Adaptive Performance and Counterproductive Behavior. It is found that work life flexibility predicts work performance as $\mathrm{F}(1,177)=106.091, \mathrm{p}<0.05, \mathrm{R}=0.612, \mathrm{R}^{2}=0.375, \beta=0.612, \mathrm{t}=10.30$, $\mathrm{p}<0.05$. It was also found that Gender has no significant effect on work life flexibility and work performance as: $F(2,176)=0.361$ and Wilks' Lamda $=0.697>0.05$, Partial Eta Square $=0.004$. The findings of the study were discussed in line with the extant literature and the results of the analyzed data.It was therefore recommended that the IT companies should give due attention to the findings of the study. This study also suggests that the future direction of research should focus on work life flexibility and organizational commitment, employee engagement, absenteeism of employees of IT companies and also this study can be linked to the other sectors.
\end{abstract}

Keywords: Work Flexibility, Work Performance, IT Companies, Employees of IT Company.

\section{INTRODUCTION}

Work life flexibility means an employer allows the employees some sort of authority that when and where they work beyond the standard working day and time. The term flexible working covers flexibility in terms of the hours that are worked and the location and includes the following: Shift working, Part-time, remote working/telecommuting, compressed working, Sabbatical/career break, Flexi-time, Job sharing, Self-roistering, Time off in lieu, Term-time working, Annual hours, Vacation-time working and many more. It enables the employees to adjust their personal and professional commitments according to the circumstances. This leads to work life balance. Work life balance plays an important role in the personal and professional achievement. Working professionals have hectic lives beyond their work and professional life. Flexibility provides an option to the employees to fulfill the demands of their personal lives. Initially the flexibility in the workplace was introduced by giving maternity leave and relaxations at workplace for women who have the care responsibility. The move taken for women as a welfare measure to maintain their valued services lead to the development of a new working culture in which employees have full anatomy to enter the workplace, maintaining the balance between work-life and family life. Moreover, not only do employees who have work flexibility tend to be more content with their work and personal lives, but they are also often more productive and harder-working. Nowadays, work life flexibility is more appropriate due to the advent of technology. The outcome of work life flexibility has been captured in the form of job satisfaction, reduced workplace stress, financial and nonfinancial growth, work life balance and job environment. Employee's performance is the key factor for an organization to survive in the cut throat competition. Individual performance plays 
an important role for higher level of organizational performance.

The high performance of an individual in accomplishing tasks results in satisfaction, feelings of self-efficacy and mastery (Bandura, 1997,Kanfer et al., 2005). There are number of measures of job performance used over the past decades (Campbell et al., 1990; Viswesvaran et al., 1996). To assess the job performance, the measures used are: tests of job knowledge, handson job samples, rating scales and archival records (Campbell et al., 1990). The most frequent way of measuring work performance of the employees are performance ratings by peer and supervisor rating (Viswesvaran et al., 1996). In this research study the individual performance of the employees is measured through self-rating. The components considered for work performance are: Task Performance, Adaptive Performance, and Contextual Performance \& Counterproductive Work Behavior. This research considers two important constructs: work life flexibility and work performance and finds the relevance of work life flexibility on work performance.

\section{THEORETICAL BACKGROUND}

Human beings are not only wage earning labors; they are the purposeful resource of an organization. Human Resource plays an important role in organizational productivity or performance. Many employees think that flexibility in work is an opportunity and a comfort. In the research carried out by Pruchno, Litchfield and Fried, 2000, it was observed that flexible working hours increases the employee productivity and allows them to do proper scheduling to move with official \& personal life. There was a research by Konrad and Mangel (2000) on impact of work-life programs on firm's productivity concluded that work life programs increases productivity by reducing the extent to which work life conflicts interfere with work. Employees working under flexible time displayed significantly higher levels of work life balance than the others utilizing traditional fixed working time. A sample of 300 employees of MNC's in Delhi was taken for the study and it was found that flexible working enables the employee to create balance in profession working and personal life. It also facilitates to reduce stress of employees and build longer tenure at organization. Employees who are given the facility of flexible working arrangement prefer to stay longer with the organization (Deshwal P, 2016). In a study of relationship between work flexibility and job performance with the mediating variable employee commitment, it was found that there is a significant impact of time flexibility on labor productivity (Bal and DeLane, 2014).

In relation to the title, it is necessary to mention the results and findings of Waldman and Spangler (1989), they developed a model of job performance predicted by individual characteristics (experience and ability), outcomes (feedback, job security) and also by work environment. There are many studies that prove work life flexibility leads to performance. (Beltrán-Martín et al., Lepak et al., MartinezSanchey et al., Bran and Udrea andValverde et al.). It has been proven that investment in human resource increases productivity, stability, and adaptability and job performance. On the basis of the extant literature, this research study tries to find the impact of work life flexibility on work performance. The objectives of the study are as follows:

\section{Objectives:}

- To study the Work Life Flexibility \& Performance of employees in IT Sector.

- $\quad$ To find the impact of Work Life Flexibility on the Performance of employees in IT Sector.

\section{Hypotheses}

H1: There is a significant impact of work life flexibility on performance of the employees.

H2: There is a significant difference of Gender on both work lifeflexibility and work performance of the employees. 


\section{METHOD}

\section{Research Design}

This study adopted a google form survey using structured questionnaire. The independent and dependent variables of the study are work life flexibility and work performance of the employees working in IT companies of Pune.

\section{Sample Size (n)}

The sample size of the study is calculated with 95\% confidence level and $7.5 \%$ margin of error and a population proportion of 0.5 . The z-value for a $95 \%$ confidence level is 1.96 .

$$
\mathrm{n}=\frac{\mathrm{z}^{2} \times \mathrm{p}(1-\mathrm{p})}{\varepsilon^{2}}
$$

On the basis of above formula, the sample size is 171 but the researcher has received the responses from 179 respondents. There were 104 female $(58.11 \%)$ and 75 male $(41.89 \%)$. The mean age of the employees was 39 years with a standard deviation of 6.4 years. The educational qualification shows that $110(61.45 \%)$ of the respondents have master degree, 69(38.45\%) have bachelor's degree.

\section{Sampling Technique}

The sampling technique adopted for the study was judgmental sampling for selection of IT companies and convenience sampling for the selection of the employees as respondents. Structured Questionnaire was sent to the respondents through google form.

\section{Research Instruments}

\section{Work Life Flexibility (WLFQ)}

The construct Work Life Flexibility was measured considering five parameters: Job satisfaction, Workplace Stress, Financial Reimbursement, Work Life Balance and Job Environment. The scale used to measure the above parameters is Likert scale ranging from 1-5.

\section{Reliability}

The ronbach's alpha for all the five components of work life flexibility values ranges from 0.71 to 0.85 . The calculated alpha values are greater than the recommended value of 0.7 (Nunnally, 1978).

\section{Validity}

The significant value of all five components of work life flexibility:"Job satisfaction, Workplace Stress, Financial Reimbursement, Work Life Balance and Job Environment" was less than 0.05 $(0.000<0.05)$ and also based on the count value obtained for five components were ranges from 0.356 to 0.710 is greater than the $\mathrm{r}$ product moment value 0.087 for infinite degree of freedom at $5 \%$ level of significance. It means the validity condition satisfies to measure wor life flexibility by the five components.

\section{Work Performance (WPQ)}

The construct Work performance of the employees of IT Companies was measured considering four parameters: Task Performance, Contextual Performance, Adaptive Performance and Counter Productive Behavior. The scale used to measure the above parameters is Likert scale ranging from 1-5.

\section{Reliability}

The ronbach's alpha for all the four components of Work Performance values ranges from 0.75 to 0.91 . The calculated alpha values are greater than the recommended value of 0.7 .

\section{Validity}

The significant value of all four components of Work Performance: Task Performance, Contextual Performance, Adaptive Performance and Counter Productive Behaviorwas less than $0.05(0.000<0.05)$ and also based on the count value obtained for four components were ranges from 0.251 to 0.580 is greater than the $\mathrm{r}$ product moment value 0.087 for infinite degree of 
freedom at $5 \%$ level of significance. It means the validity condition satisfies to measure Work Performance by these four components.

DATA ANALYSIS

Statistical Analysis

Table 1: Regression showing impact of Work Life Flexibility on Work Performance

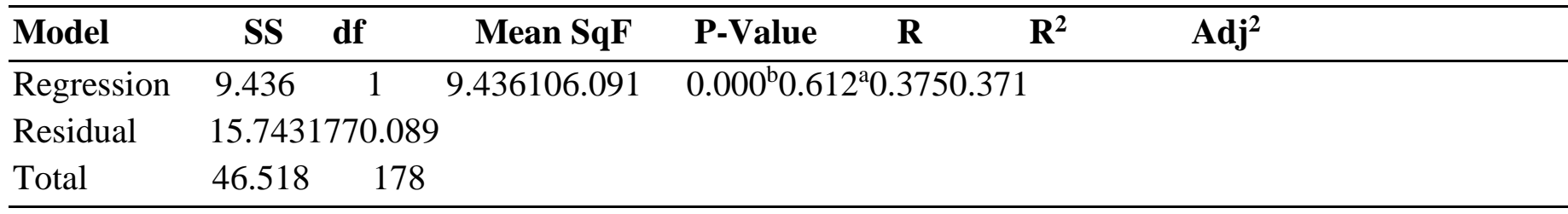

a. Dependent Variable: Work Performance, b. Predictors: (Constant), Work Life Flexibility [ $F$ $(1,177)=106.091, p<0.05, R=0.612, R 2=0.375, \beta=0.612, t=10.30, p<0.05$.]

Table 2: One Way MANOVA :effect of Gender on Work Life Flexibility and Work Performance Multivariate Tests ${ }^{\mathrm{a}}$

\begin{tabular}{|ll|r|r|r|r|r|r|}
\hline Effect & & \multicolumn{1}{|c|}{ Value } & \multicolumn{1}{c|}{ F } & Hypothesis df & Error df & \multicolumn{1}{c|}{ Sig. } & $\begin{array}{c}\text { Partial Eta } \\
\text { Squared }\end{array}$ \\
\hline Intercept & Pillai's Trace & .990 & $8764.007^{\mathrm{b}}$ & 2.000 & 176.000 & .000 & .990 \\
& Wilks' Lambda & .010 & $8764.007^{\mathrm{b}}$ & 2.000 & 176.000 & .000 & .990 \\
& Hotelling's Trace & 99.591 & $8764.007^{\mathrm{b}}$ & 2.000 & 176.000 & .000 & .990 \\
& Roy's Largest & 99.591 & $8764.007^{\mathrm{b}}$ & 2.000 & 176.000 & .000 & .990 \\
& Root & .004 & $.361^{\mathrm{b}}$ & 2.000 & 176.000 & .697 & .004 \\
\hline Gender & Pillai's Trace & .996 & $.361^{\mathrm{b}}$ & 2.000 & 176.000 & .697 & .004 \\
& Wilks' Lambda & .004 & $.361^{\mathrm{b}}$ & 2.000 & 176.000 & .697 & .004 \\
& Hotelling's Trace & .004 & $.361^{\mathrm{b}}$ & 2.000 & 176.000 & .697 & .004 \\
\hline
\end{tabular}

a. Design: Intercept + Gender

b. Exact statistic

\section{DISCUSSION AND IMPLICATIONS}

This study was conducted to find the impact of work life flexibility on work performance and the significant effect of gender on both work life flexibility and work performance.Simple Linear Regression and One Way MANOVA have been applied for the data analysis. The data collected for the analysis holds all the assumptions of simple linear regression and MANOVA as: Scale of measurement, no Outliers, normality, Linearity, Assumption of Independence, Homoscedasticity, and Homogeneity of error variance (Box M Test). The regression output shows that the significant value in the ANOVA table is $0.000<0.05$, means there is a significant impact of work life flexibility on work performance of the employees. Hence, hypothesis $\mathrm{H} 1$ is accepted. The $\mathrm{R}^{2}$ value is 0.375 , means there is a $37.5 \%$ variation in the work performance due to work life flexibility.

The One Way MANOVA has been applied to find the significant effect of Gender on work life flexibility and work performance. The significant value of Wilks' lambda is $0.697>0.05$. This means there is no significant effect of Gender on work life flexibility and work performance. Hence, 
hypothesis $\mathrm{H} 2$ is rejected, means this research is fail to reject the null hypothesis.

The findings of the study areconsistent with the earlier studies asflexible working practices facilitate work-life balance, and with shifting family patterns such practices are beneficial for both women and men. (P. Thomson (2008), E. Pruyne, M. Powell and J. Parsons (2012) and D. Hofacker and S. Konig (2013)). Furthermore, it was also found that work life flexibility increases productivity, reduces employee turnover and absenteeism (Anon,2008). This study concludes that there is an impact of work life flexibility on work performance and also there is no significant effect of Gender on work life flexibility and work performance.

\section{CONCLUSION AND RECOMMENDATIONS}

The study examined that there is a significant impact of Work Life Flexibility on Work Performance of employees in IT Companies.

The flexible working arrangements help in task performance, contextual performance, adaptive performance and counterproductive behavior. The results and findings of the study are also supported by the extant literature. The IT companies should focus on the output of the study and should provide work life flexibility to the employees. The other companies and sectors should also focus on work life flexibility for the employees for improved performance and efficiency.

\section{LIMITATIONS AND FUTURE RESEARCH}

The present study is limited to Pune and IT Companies only. The future study can be done in other sectors and also can be done in other parts of India. The future study can also cover the other dependent variables such as organizational commitment, employee engagement, employee motivation, morale, attitude and sincerity and commitment that is not covered in the present study.

\section{REFERENCES}

[1] Anon (2008), "Flexible Working as Human Resource Strategy: Benefits to the Organization and its Personnel," Strategic Direction, Vol. 24, No. 8, 2008, pp. 9-11. http://dx.doi.org/10.1108/0258054081088 4584.

[2] Bal, P.M.; De Lange, A.H. From flexibility human resource management to employee engagement and perceived job performance across the lifespan: A multisample study. J. Occup. Organ. Psychol. 2014.

[3] Beltrán-Martín, I.; Roca-Puig, V.; EscrigTena, A.; Bou-Llusar, J.C. Human Resource Flexibility as a Mediating Variable between High Performance Work Systems and Performance. J. Manag. 2008, 34, 1009-1044

[4] Bandura, A. (1997) Self-Efficacy: The Exercise of Control. New York: Freeman.

[5] Bhalla, Jaya.(2016), "Impact of Flexible Work Arrangements on Productivity in Indian IT Sector: A Study", IPE Journal of Management;

Hyderabad Vol. 6, Iss. 1, (Jan-Jun 2016): 80-104.

[6] Bran, C.; Udrea, C.I.The Influence of Motivation and Flexibility on Job Performance. Eur. Proc. Soc. Behav. Sci. 2016, 136-143

[7] Campbell, J. P. (1990), Modeling the performance prediction problem in industrial and organizational psychology. In M. Dunnette\& L. M. Hough (Eds.), Handbook of industrial organizational psychology (Vol. 1, 2nd ed., pp. 687-732). Palo Alto, CA: Consulting Psychologists Press.

[8] D. Hofacker and S. Konig, "Flexibility and Work-Life Conflict in Times of Crisis: A Gender Perspective," International Journal of Sociology and Social Policy, Vol. 33, No. 9-10, 2013, pp. 613-635. 
http://dx.doi.org/10.1108/IJSSP-04-20130042

[9] Deshwal P. (2015), Impact of FlexibleWork ArrangementinMNC'sof Delhi. International Journal of Applied Research1(13)810- 814.

[10] E. Pruyne, M. Powell and J. Parsons, "Developing a Strategy for Employee Wellbeing: A Framework for Planning and Action," Ashridge Business School, Nuffield Health, 2012.

[11] Kanfer, R. and Ackerman, P. L. (2005) 'Work competence: A Person-Oriented Perspective', in A. J. Elliot and C. S. Dweck (eds), Handbook of Competence and Motivation. Guilford Publications, pp. 336-353

[12] Lepak, D.P.; Takeuchi, R.; Snell, S.A. Employment Flexibility and Firm Performance: Examining the Interaction Effects of Employment Mode, Environmental Dynamism, and Technological Intensity. J. Manag. 2003, 29, 681-703.

[13] Marloe B. Sundo, Satoshi Fujii (2005), The effects of a compressed working week on commuters' daily activity patterns, Transportation Research Part A: Policy and Practice, Volume 39, Issue 10, 2005,Pages 835-848, ISSN 0965-8564, https://doi.org/10.1016/j.tra.2004.06.001.

[14] Martínez-Sánchez, A.; Pérez-Pérez, M.; De-Luis-Carnicer, P.; Vela-Jiménez, M.J. Telework, human resource flexibility and firm performance. New Technol. Work Employ. 2007, 22, 208-223

[15] Nunnally, J. C. (1978). Psychometric theory. New York: McGraw Hill.

[16] Pruchno, R., Litchfield, L. \& Fried, M. (2000). Measuring the Impact of Workplace Flexibility. Boston, MA: Boston College Center for Work and Family

[17] P. Thomson, "The Business Benefits of Flexible Working," Strategic HR Review,
Vol. 7, No. 2, 2008, pp. 17-22. http://dx.doi.org/10.1108/1475439081085 3129 [3]

[18] Viswesvaran, C., Ones, D. S., \& Schmidt, F. L. (1996). Comparative analysis of the reliability of job performance ratings. Journal of Applied Psychology, 81, 557574.

[19] Valverde, M., Tregaskis, O.; Brewster, C. Labor flexibility and firm performance. Int. Adv. Econ. Res. 2000, 6, 649-661

[20] Waldman, D.A.; Spangler, W.D. putting together the pieces: A closer look at the determinants of job performance. Hum. Perform. 1989, 2, 29-59. 